\title{
EVALUATION OF INVESTMENTS INTO HOUSING RENOVATION
}

\author{
Edmundas Kazimieras ZAVADSKAS ${ }^{1}$, Artūras KAKLAUSKAS ${ }^{2}$ and Saulius RASLANAS ${ }^{2}$ \\ ${ }^{1}$ Department of Construction Technology and Management, Faculty of Civil Engineering, Vilnius \\ Gediminas Technical University, Saulètekio al. 11, LT10223 Vilnius-40, Lithuania \\ E-mail: edza@adm.vtu.lt \\ 2 Department of Construction Economics and Property Management, Faculty of Civil Engineering, \\ Vilnius Gediminas Technical University, Saulètekio al. 11, LT-10223 Vilnius-40, Lithuania \\ E-mail: Arturas.Kaklauskas@st.vtu.lt; E-mail: Saulius.Raslanas@st.vtu.lt
}

Received 5 May 2004; accepted 20 August 2004

\begin{abstract}
The relevant objectives of a housing strategy is to vouch the effective usage of the present housing, maintenance and renovation. The selection of the means for building and residential environment renovation is dictated by the drawbacks of their present state, out-of-date designed decisions, natural physical deterioration. While fixing the optimal renovation prices from the aspect of market value increase, the main indicator, limiting the size of investments into building renovation, is the difference between market values after and before renovation. The difference between $1 \mathrm{~m}^{2}$ of market value of a building of new construction and the average price of $1 \mathrm{~m}^{2}$ of a building of old construction and the cost of renovation means for it will decide the size of the packet of the investments into renovation.
\end{abstract}

KEYWORDS: Renovation; Market value; Housing; Market value ratio

\section{INTRODUCTION}

One of the most relevant objectives of the housing strategy [7] confirmed by the Government of the Republic of Lithuania is to vouch the effective usage of the present housing, maintenance, renovation, update, the rational usage of energy resources, substantially to improve the state of the available housing fund, to retain and increase its value. A key issue in property investment is the wasting asset in the building component that depreciates over time and requires constant upgrading to maintain market position [11|. The onset of depreciation and obsolescence over time tends to reduce both income and value. Capital investment is required to reverse this situation. Aiming at reaching the desirable effect of building renovation, the right decision how to improve the image of separate city areas and to increase housing eco-friendliness and economy [4] should be made. It is necessary to evaluate whether building renovation can aid to achieve the desirable level of area attraction and whether that is economically effective. In Gorgolewski's opinion [2], in order for the energy saving measure to be profitable, the value of energy saved over its life will need to be greater than the capital investment and optimisation would involve the selection of all measures with the savings-to-investment ratio (SIR) above 1 , where

$$
S I R=\frac{\text { Present value of the total lifetime energy saving }}{\text { Investment cost }}
$$

To calculate the SIR, the "present value" of the total energy saved must be found. The present value concept allows cash flows occurring over a wide time-scale to be considered at 
their equivalent value relative to today's prices. This requires the discounting of all future savings to their equivalent present value using

$$
P V_{c}=C\left[\frac{1-(1+r)^{-n}}{r}\right]
$$

This gives the present value, $P V_{C}$. for an annual saving C, occurring for $n$ number of years (lifetime of measure), with a real discount rate of $r$.

According to Martinaitis et al. [8], the refurbishments implementation of benefits of some energy saving measures is associated not only with energy saving, but also with the improvement of building element conditions, durability and the value of a building. To have a more objective evaluation, it is more applicable to use other fundamental criteria for the evaluation of the cost effectiveness-a net present value $(N P V)$ and an internal rate of return (IRK).

In paper [1] is shown, that coherent and efficient retrofit scenarios are commonly built on the basis of the knowledge of the degradation state of the building and its obsolescence, also this paper describes a systematic method, based on multicriteria analysis and a const-ructivist approach, which helps an expert in designing retrofit scenarios.

According to Miljan et ai. [9], the connections between value and cost as well as their actual conclusion into economic considerations are important. In paper [3] have dealt with how to optimise retrofit measures, i.e. how to act in order to minimise the Life-Cycle Cost (LCC) of a building.

The economic aspect of renovation is also very important and should be analysed from the perspective of the market value of property. The authors of the present paper made the analysis of renovation of multistorey apartment houses in Vilnius and provided some recommendations.

\section{RENOVATION PROJECTS OF APARTMENT BUILDINGS IN VILNIUS}

About $59 \%$ of apartments in dwelling houses in Vilnius are located in large-panel buildings. In brick and cast-in-place buildings they take $35 \%$ and $6 \%$ of all apartments in multifamily buildings, respectively. The types of buildings are not numerous. They include about seven varieties of large-panel houses, six types of brick and four types of cast-in-place buildings. Major problems associated with maintenance as well as defects and drawbacks found in panel houses are common to all such buildings constructed in the period from 1960 to 1996 . Usually, the enclosure walls of these houses have poor thermal characteristics. In later structures, the requirements to these parameters are more rigorous. Therefore, considering these buildings from the economical point of view it may be stated that thermal insulation of some of their enclosures is by 4 - 4.5 times lower than specified by the regulations.

This means that to make the above houses economical, thermal insulation of enclosures should be improved. Another problem of the most of apartment buildings is not associated only with high thermal conductivity of their windows and doors, but is related with poor sealing caused by natural ageing and low quality of building products. As a result, in winter, cold air can easily infiltrate into the spaces and heat losses due to ventilation are also increased. Many problems arise in large-panel buildings (especially in the older ones) because of leaking joints between panels. Due to this, the walls are getting damp and even frozen (in cold weather). The interior finishing of the apartments is damaged, thermal conductivity of walls and heat losses increase, worsening the microclimate of the spaces. The balconies in large-panel and in some brick houses are in a bad (sometimes, emergency) state. In brick houses, signs of wetting, crumbling and freezing of an external ceramic brick layer may be observed. In cast-in-place buildings some joints between floor slabs are not well sealed because 
the concrete was not properly compacted, thereby leaking water which sometimes penetrates the walls and gets into the wall cavity

Roofs of apartment buildings are usually flat, covered with rolled material (e.g. ruberoid on the bituminous base) and having the internal water removal. Nearly all such roofs are characterized by heavy wearing of the covering and its bubbling. They also may leak water, especially near the parapets and water catchers. In brick houses, the walls often get damp if water leaks near the parapets.

All the above problems and defects indicate the need for innovation of Vilnius apartment buildings and of their surroundings. Therefore a demand for heating in these houses is two or more times higher than in those in Western countries [6].

Different scenarios of buildings renovation may be used. Four variants of renovation projects aimed to determine preliminary investments and their effectiveness have been prepared (Table 1). They include a set of small investment projects, a set of medium investment projects, a set of large investment projects and a "basic" set of renovation projects. Besides, the calculations of several types of large-panel apartment buildings have been made.

Table 1. Characteristics of the packets of investments implements into renovation for large-panel building of the type 120V-06/1

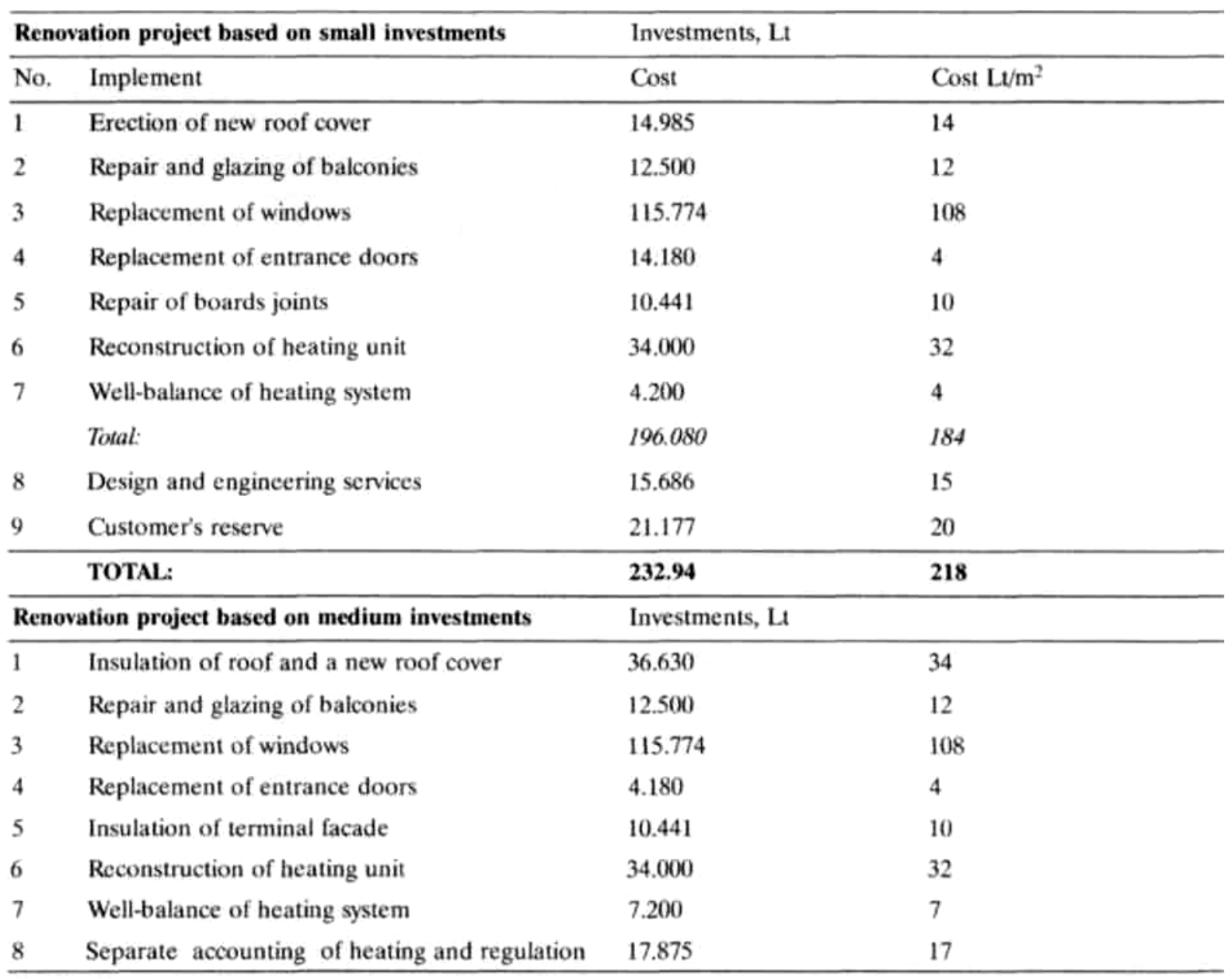




\begin{tabular}{|c|c|c|c|}
\hline \multirow[t]{2}{*}{9} & Arrangement of the environment & 42.760 & 40 \\
\hline & Total: & 281.360 & 263 \\
\hline 10 & Design and engineering services & 22.509 & 21 \\
\hline \multirow[t]{2}{*}{11} & Customer's reserve & 30.387 & 28 \\
\hline & TOTAL: & 334.256 & 313 \\
\hline \multicolumn{2}{|c|}{ Renovation project based on large investments } & \multicolumn{2}{|l|}{ Investments, $\mathrm{Lt}$} \\
\hline 1 & Erection of pitched roof and new dwelling & 36.630 & 34 \\
\hline 2 & Repair and glazing of balconies & 65.000 & 61 \\
\hline 3 & Replacement of windows & 115.774 & 108 \\
\hline 4 & Replacement of entrance doors & 4.180 & 4 \\
\hline 5 & Insulation of facade & 154.686 & 145 \\
\hline 6 & Reconstruction of heating unit & 34.000 & 32 \\
\hline 7 & Reconstruction of heating system (collector) & 170.000 & 159 \\
\hline 8 & Replacement of water pipes & 43.829 & 41 \\
\hline 9 & Replacement of electrical equipment & 4.455 & 4 \\
\hline \multirow[t]{2}{*}{10} & Arrangement of the environment & 42.760 & 40 \\
\hline & Total: & 671.314 & 628 \\
\hline 11 & Design and engineering services & 53.705 & 50 \\
\hline \multirow[t]{2}{*}{12} & Customer's reserve & 72.502 & 68 \\
\hline & TOTAL: & 797.521 & 746 \\
\hline \multicolumn{2}{|c|}{ Renovation project based on "basic" investments } & \multicolumn{2}{|l|}{ Investments, Lt } \\
\hline 1 & Insulation of roof and a new roof cover & 36.630 & 34 \\
\hline 2 & Repair and glazing of balconies & 65.000 & 61 \\
\hline 3 & Replacement of windows & 115.774 & 108 \\
\hline 4 & Replacement of entrance doors & 4.180 & 4 \\
\hline 5 & Insulation of facade & 154.686 & 145 \\
\hline 6 & Reconstruction of heating unit & 34.000 & 32 \\
\hline 7 & Well-balance of heating system & 7.200 & 7 \\
\hline 8 & Separate accounting of heating and regulation & 17.875 & 17 \\
\hline \multirow[t]{2}{*}{9} & Arrangement of the environment & 42.760 & 40 \\
\hline & Total: & 478.105 & 447 \\
\hline 10 & Design and engincering services & 38.248 & 36 \\
\hline \multirow[t]{2}{*}{11} & Customer's reserve & 51.635 & 48 \\
\hline & TOTAL: & 567.989 & 532 \\
\hline
\end{tabular}

A set of renovation projects based on small investments is oriented to the replacement, reconstruction or repair of building elements which are in the worst technical conditions. This alternative is attractive because it is rela- tively cheap, but thermal characteristics of building enclosures are not improved much (except for doors and windows). The same applies to the architectural appearance and aesthetic characteristics of buildings. Another 
drawback is not sufficiently accurate calculation of thermal power consumption in the apartment (based on living space) and unavailability of temperature regulation in spaces.

A set of renovation projects based on medium investments is aimed at energy saving. It can provide rather high economic effect. The possibility to regulate temperature in the apartments and individually determine thermal energy consumption encourage the tenants to save energy. These savings may be relatively large. The alternative also provides for minimum outdoor amenities. However, the aesthetic view of a building is not considerably changed according to this renovation variant and the walls can hardly satisfy the currently used standards. There are also some drawbacks relating to the calculation of thermal energy consumption and temperature regulation in particular apartments. Thus, all thermal energy consumed in the house is proportionally distributed among the apartments according to indication of their meters. Moreover, in the case of repair or break-down in one of the apartments, heat will not be supplied to others. Tenants cannot start heating their premises before the heating season begins.
Projects based on large investments are aimed at providing the highest quality to a building, which would have the enclosures with thermal characteristics satisfying the standards, as well as possessing more advanced heating system allowing for accurate calculation of heat energy consumption and individual temperature regulation at any time. From the economic point of view such houses are most effective, satisfying the standards specified for new construction. However, the investments are large $\left(746 \mathrm{Lt} / \mathrm{m}^{2}\right)$ being hardly affordable for an average-income family. This alternative is most suited for prestigious residential areas. Pitched roofs would allow to arrange additional apartments which could be sold.

A "basic" set of projects means the most primitive renovation scenario providing for building enclosures satisfying more advanced heating standards and individual metering of thermal energy consumption. Basic projects also provide for minimum outdoor amenities.

The investment per $1 \mathrm{~m}^{2}$ of total building area for various types of large-panel buildings according to renovation projects based on medium-size investments is shown in Figure 1.

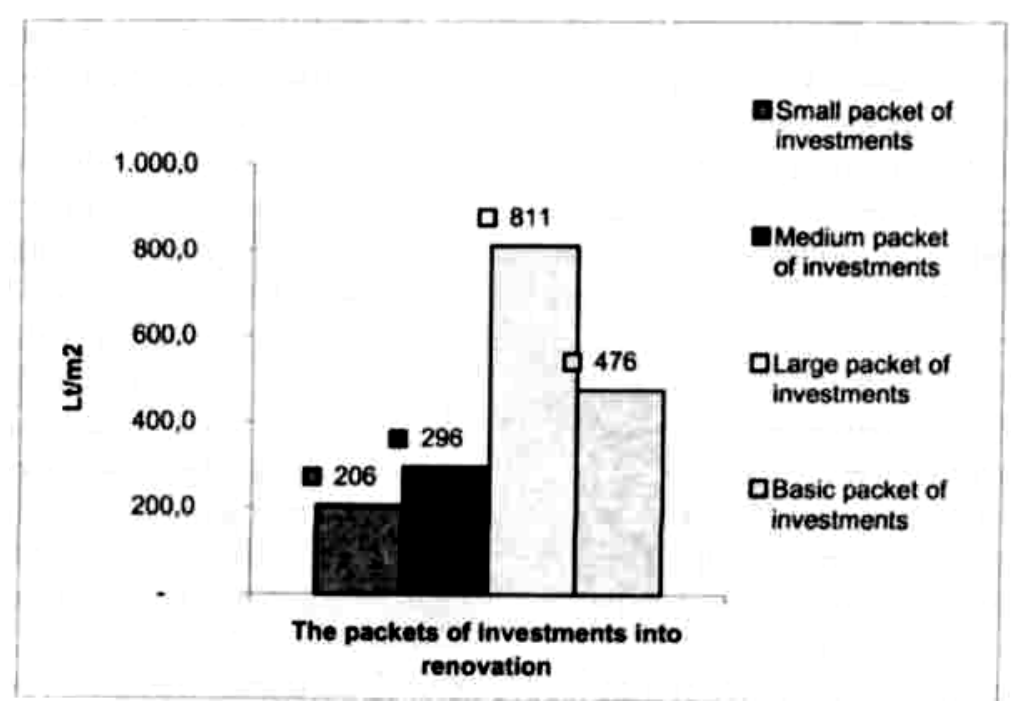

Figure 1. Average investments into the renovation projects 
For projects based on small investments in renovating various type apartment buildings the expenses range from $181 \mathrm{Lt} / \mathrm{m}^{2}$ to $221 \mathrm{Lt} / \mathrm{m}^{2}$, i.e. 206 $\mathrm{Lt} / \mathrm{m}^{2}$ on the average. Assuming that all apartments are similar, the investments per one apartment range from $9371 \mathrm{Lt}$ to $12401 \mathrm{Lt}$, i.e. $10827 \mathrm{Lt}$ on the average. The average cost of implementation of medium-size investment projects of large-panel buildings renovation is $296 \mathrm{Lt} / \mathrm{m}^{2}$ (ranging from 262 to $319 \mathrm{Lt} / \mathrm{m}^{2}$ ). Consequently, the average investment into one apartment renovation would make $15569 \mathrm{Lt}$ (ranging from $13921 \mathrm{Lt}$ to $18329 \mathrm{Lt}$ ). The average cost of large investment projects would be $811 \mathrm{Lt} / \mathrm{m}^{2}$ or $42.616 \mathrm{Lt}$ for one apartment (ranging from 684 $\mathrm{Lt} / \mathrm{m}^{2}$ to $946 \mathrm{Lt} / \mathrm{m}^{2}$ or from $35701 \mathrm{Lt}$ to $54254 \mathrm{Lt}$ for one apartment). The execution of a "basic" set of projects would require about $476 \mathrm{Lt} / \mathrm{m}^{2}$ or $25146 \mathrm{Lt}$ for one apartment (ranging from $432 \mathrm{Lt} / \mathrm{m}^{2}$ to 532 $\mathrm{Lt} / \mathrm{m}^{2}$ or from $20720 \mathrm{Lt}$ to $29681 \mathrm{Lt}$ for one apartment).

\section{PRICES OF URBAN APARTMENTS}

Prices analysis was made of apartments in socalled "bedroom" districts in Vilnius where multistorey residential buildings prevail. Such districts as Antakalnis, Fabijoniškès, Justiniškès, Karoliniškès, Lazdynai, Naujininkai, Naujoji Vilnia, Paneriai, Pašilaičiai, Pilaitè, Šeškinè, Šnipiškès, Verkiai, Vilkpèdè, Viršu-liškès, Žirmūnai and Žvèrynas were considered. A regression-correlation analysis based on apartment prices in SeptemberNovember 2003 was also performed. The following main factors influencing the price of a particular apartment were analysed: location (district), type and age of building, floor, general state of apartment, living space, the environment (noise and pollution) and a criminogenic situation.

In general, it can be stated that the most important factors determining the price of apartments are the location (district), type of building, time of construction and state of an apartment. The location (district) has the strongest influence on the apartment value. Prices depending on district prestige differ by about
$25 \%$. The type of building has also a considerable effect on the apartment value. Apartments in brick houses are most valued. Then come the apartments located in cast-in-place buildings. The lowest value have the apartments which are in panel houses, with $1 \mathrm{~m}^{2}$ of their living space valued by $15 \%$ lower than that of brick house apartments. The type of building is most important in Paneriai, Pilaite and Pašilaičiai districts.

The age of the house is also very important in many districts. The highest value have the apartments in houses built later than in 1996. This may be accounted for their better lay-out, higher level of comfort and economic maintenance. According to the age of a building, prices vary from $15 \%$ to $20 \%$. In this respect, the highest influence on price can be observed in Justiniškès, Paneriai, Šnipiškès, Pašilaičiai, Vilkpèdè and Viršuliškès districts. It has also been stated that the influence of the floor is insignificant. It is more important in Antakalnis and Šnipiškès because the city center may be seen from these places.

The state of an apartment is the third most important factor determining its price in Vilnius. With the development of new technologies and building materials, the apartments may be renovated to satisfy the European standards. This has a great influence on their price. Apartments which are well repaired and provided with all modern amenities have the highest value. Prices depending on the state of the apartment range from $15 \%$ to $20 \%$.

The living space of the apartment is not very important, though one- and two-room apartments are most highly valued. This may be accounted for constantly growing bills for services. In this respect, the situation is different only in the prestigious districts of Antakalnis and Žvèrynas where large three- or four-room apartments are also valued. It can be observed that living space is most important in Šeškinè, Karoliniškès, Žirmūnai and in so-called "bedroom" districts where residents would like to have apartments with relatively low maintenance cost. 
With respect to location, a criminogenic situation in a district is most important. This shows that people prefer place with a higher safety level. Noise and pollution of the environment have a slight effect on the apartment price, because in the prestigious districts where prices are the highest, these problems also exist.

In Vilnius, the prices of apartments in multistory houses vary considerably depending on a particular district. Average prices of two-room apartments in 1998-2003 are given in Figure 2. The prices of $1 \mathrm{~m}^{2}$ living space are by three-room apartments about $17 \%$ lower compared to the prices of one-room apartment during the whole period analysed. In 1999, the prices of one- and two-room flats rose by about $45 \%$, compared to 1998 , therefore, the difference between them had not changed much, making about $7 \%$. In 1999 , the price of three-room apartments rose by about $33 \%$ compared with 1998. The difference between the cost of $1 \mathrm{~m}^{2}$ of living space in one- and three-room flats increased from $9 \%$ in 1998 to about $16 \%$ in 1999.

In 2000, real estate prices dropped, with the cost of $1 \mathrm{~m}^{2}$ of area in one-room apartment dropping by $17 \%$ and in two- or three-room apartments by $22 \%$. The difference in prices for one- and two- or threeroom flats was still increasing because of the decreasing price of the latter. During 2001, the prices were still lowering. The price of one-room apartment decreased by about $19 \%$ compared to that in 2000 . Two- and three-room flats became cheaper by about $13 \%$ and $12 \%$, respectively. The difference between real estate prices became smaller. In 2001, a new price rise of $1 \mathrm{~m}^{2}$ of living space was observed. In 2003, in many districts, real estate prices reached the level of the year 2000 and in some areas rose even higher, exceeding them by about 5-10\%. However, the analysis of price dynamics shows that the current real estate prices, having reached the level of 2000, are still lower than the highest prices reached in 1999. For the last three years, real estate prices have been growing steadily, however, taking into account the current standard of living, it can hardly be expected that they would reach the EU real estate prices in the nearest future.

Analysis of new construction market has shown that the availability of soft loans had not considerably changed the demand for expensive apartments (with the price from $2000 \mathrm{Lt} / \mathrm{m}^{2}$ ) (Figure 3 ). However, every year more apartments of this type are bought.

In 2001, about 80 per cent of real estate customers purchased apartments taking either soft or commercial loans, while in 2000 , only 30 per cent of inhabitants used loans. Thus, during 2001 the demand for newly-built apartments and the number of loans were increas-

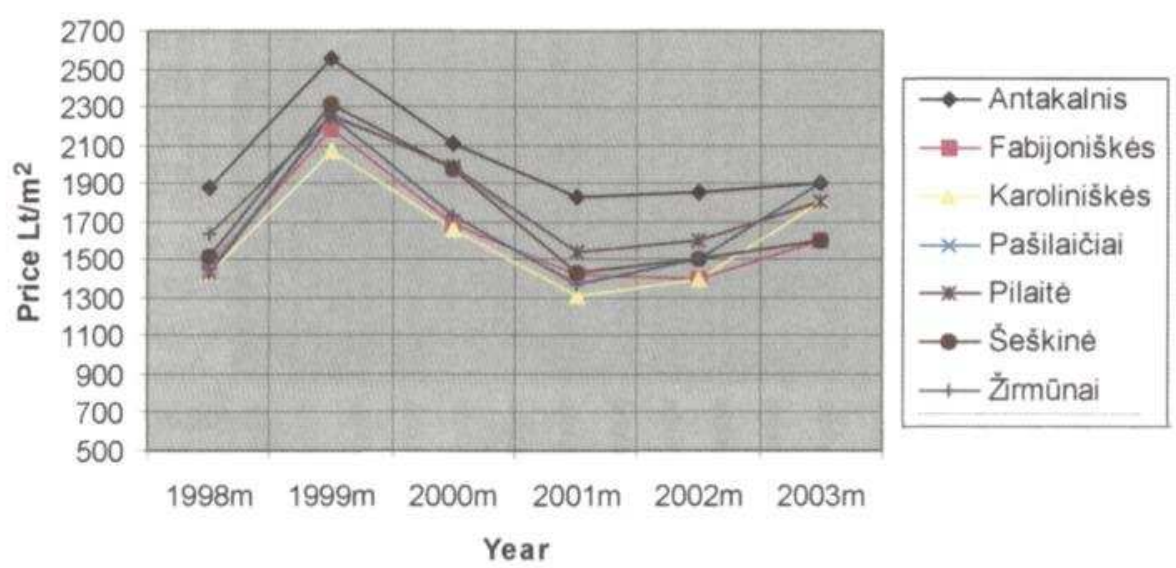

Figure 2. The dynamics of two-room apartment prices in the buildings of various districts 
ing, while bank interest on credit and credit terms were decreasing. The competition in this area was also growing. In 2003, after Lithuanian inhabitants voted for joining the European Union it was considered that real estate prices would grow and the demand for it considerably increased. It was accompanied by the price rise which still continues. Now, two main trends can be observed in real estate purchasing: people buy either relatively cheap one- or two-room standard apartments in "bedroom" districts or newly-built apartments with partial finishing.

The economic situation of the country also plays an important role in determining real estate prices. The economy of Lithuania has been growing since 2000. Low inflation rate is maintained and gross national product increased by $9.0 \%$ (6.5\% in 2001), which is the highest value in the states of the Baltic region. If the external conditions are favourable, further increase may be expected. For the first time the economic growth was determined by the increased demand in the domestic market in 2002. A continuous growth can be observed in the real estate sector.

\section{ANALYSIS OF INVESTMENTS INTO APARTMENT BUILDINGS RENOVATION}

A number of factors should be considered in order to determine the proper amount of investments into the renovation of apartment buildings. This is largely determined by the need for financing to achieve the aims set in renovation and by the available financial assets. Considerable changes in the architectural appearance and maintenance costs of a building would require $300-500 \mathrm{Lt} / \mathrm{m}^{2}$ (of the apartment living space).

The factor of cost effectiveness is also important. It shows what benefits or profit can be expected from the investment into the renovation of dwellings. The main goals of apartment building renovation are to make dwellings more economical and environmentally-friendly as well as creating better outdoor amenities (which would increase the attractiveness and competitiveness of the city). The economic effect of renovation can be described in terms of the payback of investments and the change in the market value of dwellings.

Since thermal characteristics of building enclosures are improved and the efficiency of

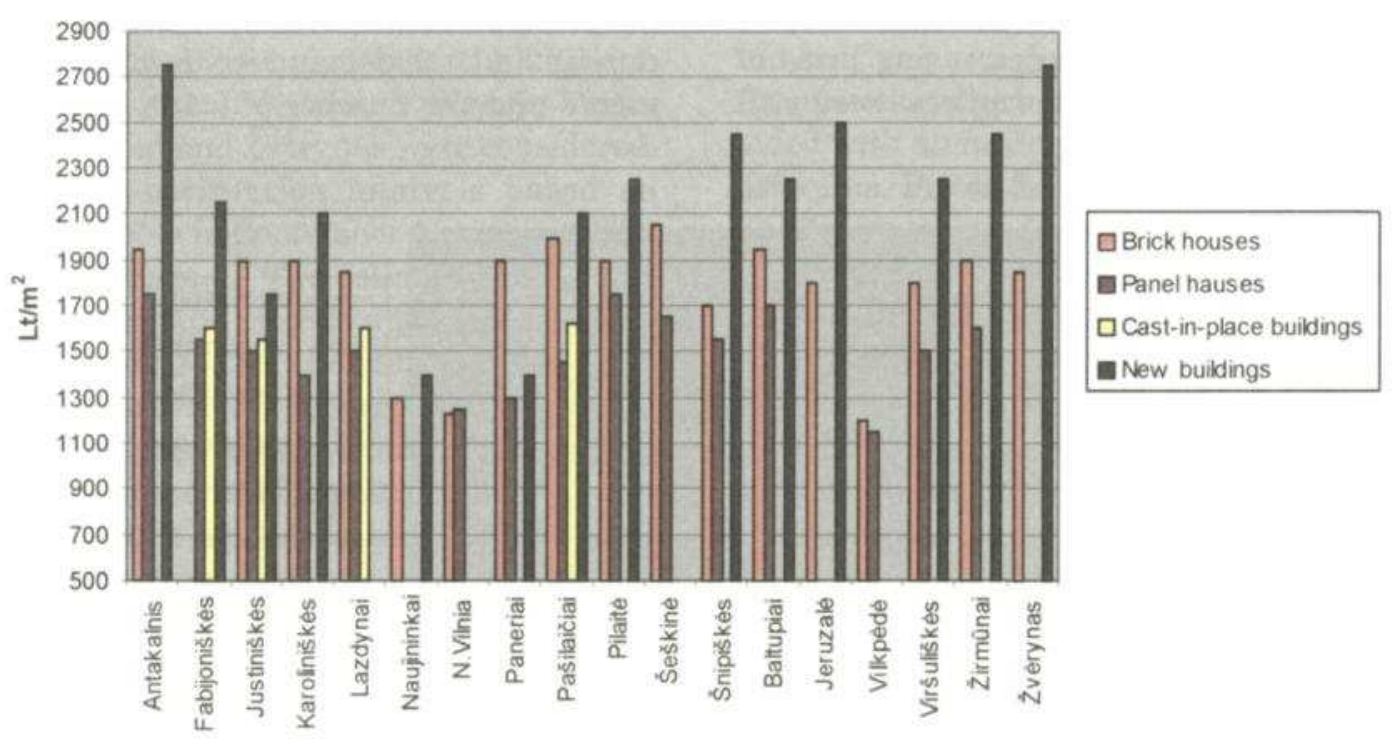

Figure 3. Prices of $1 \mathrm{~m}^{2}$ living space in 3-room apartments in various types of buildings 
the heating system increased due to renovation, a building will be more energy-efficient and its maintenance costs will be lower. Short-term payback of investments shows that the economic effect of renovation is high. However, it is not advisable to assess renovation only from this perspective. The case may be when a longer payback period of large investments will lead to higher savings and, therefore, greater economic efficiency $[2,81$. Then, the period considered is limited by the remaining service life of the renovated parts and the building itself. Economically efficient renovation is that when the payback period is shorter than the remaining service life of the renovated parts or the building itself. The remaining service life of the renovated parts of the building analysed is longer than 40 years. Judging by the technical state of their structures, the remaining service life of the most of apartment buildings is about $30-50$ years. However, this period may even be shorter because of the physical wear, depreciation and other factors. However, according to preliminary calculations, the renovation of dwellings should pay back in 30-40 years. The payback of all renovation scenarios may take about 30 years, except for renovation projects based on large investments which, depending on the type of buildings, may pay back at least in 32 years. An average cost of this renovation scenario implementation is $800 \mathrm{Lt} / \mathrm{m}^{2}$ (of the apartment living space) or $43000 \mathrm{Lt}$ per one conditional apartment. Therefore, for the investment to be profitable, the renovation cost of a building taking into account yearly inflation should not exceed $600-700 \mathrm{Lt} / \mathrm{m}^{2}$. It should be mentioned, that the above renovation cost should not discourage the construction of new apartments on the flat roofs of the existing five-story buildings in more attractive districts (i.e. Antakalnis, Žirmūnai) by erecting pitched roofs, because, in this case, it would not be the renovation but rather the creation of new real estate. Besides, this would make a building more attractive and economical.

Considering the optimal cost of building renovation from the perspective of its market value increment, the limit will be the difference between the market value of a particular building before and after renovation. This is for a very simple reason: any real estate owner is not going to invest more into his property than the expected increase in its market price after renovation, because he hopes to get some profit if he sells it. With a few examples of renovated apartment buildings, it is difficult to predict the actual market price of $1 \mathrm{~m}^{2}$ of the apartment living space after the renovation according to at least one of the considered scenarios. However, it is evident that it would not exceed the price of $1 \mathrm{~m}^{2}$ of new dwellings, even for the case of large investments, because they would not eliminate all defects caused by wearing. The differences in the construction cost between apartment buildings constructed in the soviet years and modern buildings vary considerably, ranging from $\sim 260 \mathrm{Lt} / \mathrm{m}^{2}$ for one-room apartments (in Naujininkai, Žemieji Paneriai, Vilkpède) to 1010 $\mathrm{Lt} / \mathrm{m}^{2}$ for three-room dwellings in the 'bedroom' districts - Karo-liniškès, Lazdynai, Žirmūnai, Pilaitè, Justiniškès, Fabijoniškès, etc. Therefore, from this point of view, the renovation is not equally effective in various districts. In less attractive districts (Naujininkai, Paneriai, Vilkpèdè, Naujoji Vilnia, Grigiškès), where renovation of buildings is given the priority for strategic purposes of the expansion of the city, it is hardly profitable. This proves the need for making these districts more attractive by improving their architectural appearance, outdoor amenities, etc. which would attract investments and help to create new working places. The differences in the cost of two-room apartments in non-renovated houses built in the soviet years and now are not closely related to the geographical position of a district ranging from $450 \mathrm{Lt} / \mathrm{m}^{2}$ to $790 \mathrm{Lt} / \mathrm{m}^{2}$. The greatest difference was observed between the apartments in new houses and old large-panel buildings located in 'bedroom' districts. One the one hand, it shows the need for the renovation of largepanel buildings but, on the other hand, defines the limits 
of profitability of investment into the renovation of such buildings. Assuming that the cost of renovated dwelling will remain by about $15-20 \%$ lower than that of a newly-built apartment, the cost of new apartments in 'bedroom' districts is - $2350 \mathrm{Lt} / \mathrm{m}^{2}$, while the cost of the existing large-panel buildings is $1560 \mathrm{Lt} / \mathrm{m}^{2}$. Besides, $15 \%$ profit is expected (the increment of the market value exceeding the investment by $15 \%$ ). The largest investment into the renovation is $\sim 370 \mathrm{Lt} / \mathrm{m}^{2}$. Since the apartments in brick houses are more expensive than those in largepanel buildings, the investment into their renovation should be even smaller, making about $170 \mathrm{Lt} / \mathrm{m}^{2}$. These calculations are rough, not taking into account cost variations of dwellings in different districts. Before starting the renovation, cost analysis of dwellings should be made in every district. For the sake of comparison, the market values of apartments in newly built and old houses and the investments associated with various renovation scenarios may be considered (Figure 4).

It can be seen in the graph, that, in terms of the value increment, it is not economical to implement the renovation scenario based on large investments in Karoliniškès (the cost of erection work is about 794 $\mathrm{Lt} / \mathrm{m}^{2}$ ). The effectiveness of a basic renovation project is practi- cally null in this district, therefore it is not advisable either. The same applies to Lazdynai. In Vilkpède district even the renovation scenario based on medium-size investments is not effective, therefore, only small investment projects may be recommended there now (with the cost of erection work being about $182 \mathrm{Lt} / \mathrm{m}^{2}$ ). The best investment prospects can be observed in Žirmūnai district, because the cost of new dwelling construction there exceeds the value both of old apartments and the most expensive renovation scenario. The situation in Viršuliškès is also favourable for renovation. In this case, a basic renovation scenario may be sufficiently effective, taking into account the increase of the market value of a renovated flat.

The comparative cost analysis of $1 \mathrm{~m}^{2}$ area in large-panel and newly-built houses has shown that its cost differs from district to district, irrespective of the type of panel buildings. In this respect, three groups of districts may be established: prestigious districts (Antakalnis, Žirmūnai, Viršuliškès) where the cost of $1 \mathrm{~m}^{2}$ living space in new dwellings is higher than the respective cost of old apartments and the cost of renovation based on the most expensive scenario. The second group includes the districts of Fabijoniškès, Karoliniškès, Pašilaičiai and Pilaitè. Here, the cost

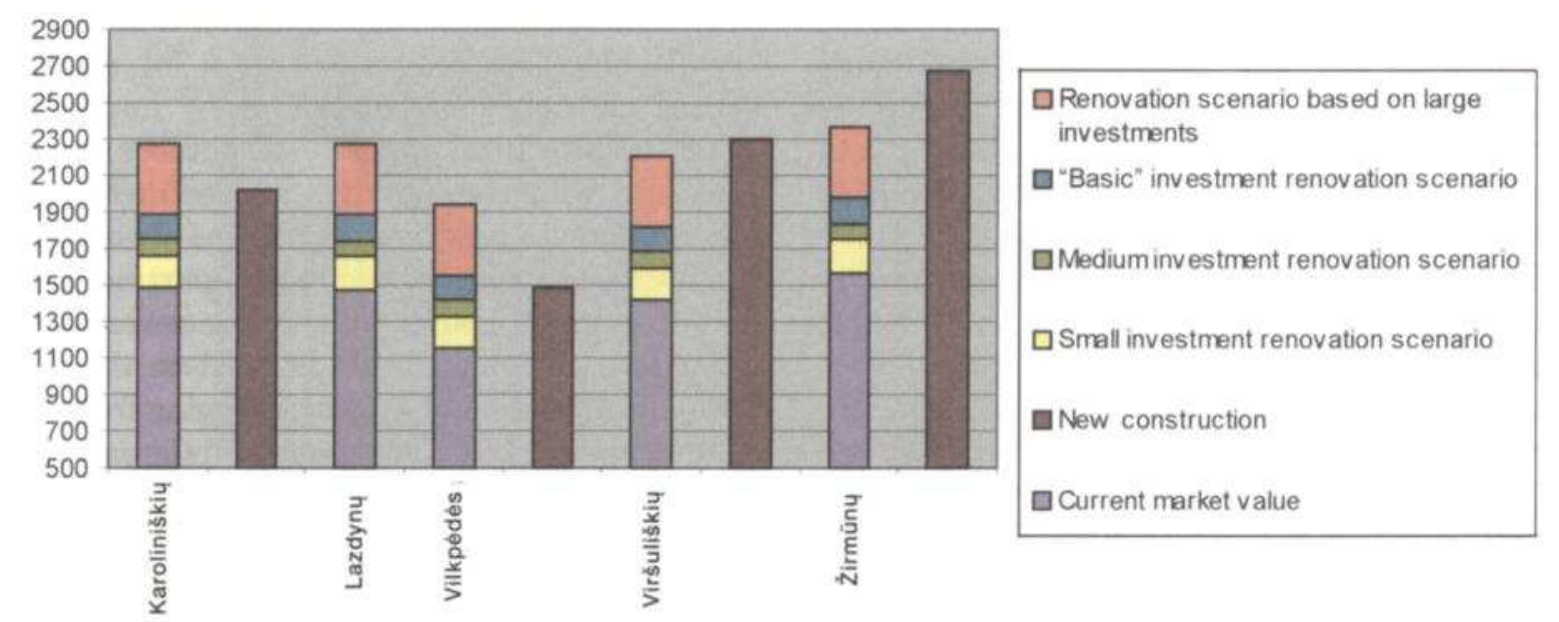

Figure 4. Prices of apartments ( $1 \mathrm{~m}^{2}$ of living space) in large-panel building of the type 11-464LI-18/1 
of renovation according to large investment scenario reaches that of a new apartment. The third group comprises non-prestigious districts (Justiniškès, Paneriai, Vilkpèdè) where the renovation cost exceeds the difference in cost between newly-built and old dwellings.

The engineering projects of renovation are very important. To evaluate them, multicriteria analysis may be used involving the experts in this field [12]. For example, a special questionnaire should be filled by experts to get their opinion about the type of windows (they should provide the values and weights of various criteria) to be used in a renovated property. Then, the data are processed and the most effective alternative is chosen, which could satisfy all interested parties.

\section{MARKET VALUE CRITERION FOR EVALUATION OF RENOVATION}

There is evidential experience that the cost of renovation is not immediately the market value, as there exists the difference between them known as the acceptance of the market. The acceptance of the market as the basic linkage between the cost and value of building may consider is basic parameters symmetric or asymetric.
The price increment depends on the cost of renovation scenario. Taking into account the increment of the renovated dwelling market value, it is hardly advisable to execute the renovation projects which would result in a particular apartment price rise to the average market value of a newly-built dwelling or even higher. From the aspect of real estate market value, the effective renovation may be described by the following market value ratio (MVR):

$$
M V R=\frac{\left(M_{v a}-M_{v b}\right)}{C_{r}},
$$

where: $M_{v a}$ - market value of building after renovation; $M_{v b}$ - market value of building before renovation; $C_{r}$ - renovation costs of building. If the packet of investments implements into renovation has an $M V R$ greater than 1, the packet can be regarded as cost effective from the aspect of real estate market value. In case of multistorey apartment buildings, the effective renovation may be described:

$$
M V R=a \cdot\left(M_{v n}-M_{v o}\right),
$$

where: $M_{v n}$ - market value of $1 \mathrm{~m}^{2}$ of new dwelling area; $M_{v o}$ - market value of $1 \mathrm{~m}^{2}$ of old dwelling area; a - the average coefficient of correction ranging within 0.8 depending on a particular district where renovation is made.

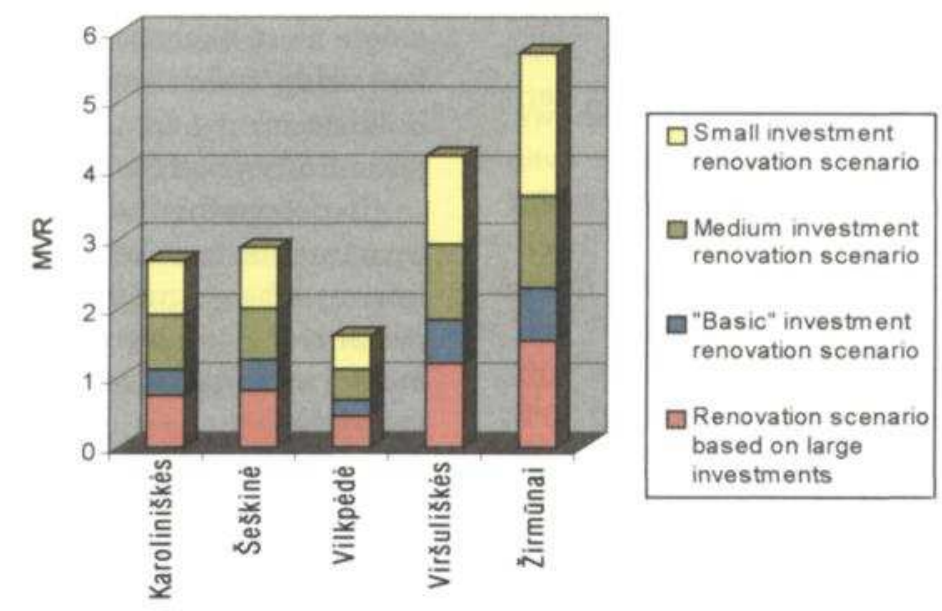

Figure 5. Market value ratios (MVR) for evaluation of renovation projects variants 
The effectiveness of variants of renovation projects for various city districts and types of buildings was calculated by $M V R$ (Figure 5).

It is evident that the renovation project based on large investments is effective in the districts Žirmūnai and Viršuliškès, in the district Šeškinè the renovation project based on "basic" investments is effective, but in the district Karoliniškès the renovation project based on medium investments is effective because in that cases $M V R>1$. On the other hand small investments into renovation have slight influence to market value and in case of the district Vilkpede only the renovation project based on small investments is effective. The packet $k$ of investments implements into renovation can be regarded as cost effective from the aspect of real estate market value, when:

$$
\begin{aligned}
& M V R_{k}>1, \\
& M V R_{i} \ldots M V R_{k-1}<M V R_{k}< \\
< & M V R_{k+1} \ldots M V R_{n},
\end{aligned}
$$

where: $i \ldots n$ - number of packets of investments implements into renovation. From the aspect of value, the effective renovation of commercial properties and public buildings may be described by the following capital value ratio $(I V R)$ :

$$
I V R=\frac{\left(I_{v a}-I_{v b}\right)}{C_{r}},
$$

where: $\mathrm{I}_{v a}$ - capital value of building after renovation; $\mathrm{I}_{v b}$ - capital value of building before renovation.

As the experience of foreign countries shows, the market value of dwelling starts to grow even before the renovation proceeds in a particular district [5]. The increase in the price of dwelling after renovation may be expected if the market price of a renovated apartment is considerably lower than the value of a newly-built dwelling. The gap should make about 20-30\%. Since the market value of renovated real estate is approaching that of new dwelling, this would influence new housing construction, the value of which could be increased. The owners of old dwellings are encouraged to rise the qua- lity of their property if they want to sell it. Therefore, a new market segment aimed to upgrade old real estate which would influence the prices of newly-built apartments will emerge. The renovation programs of apartment houses should also encourage the tenants to establish the associations of real estate owners.

In nearly all renovated buildings only two or three renovation projects were implemented. They mainly concerned the replacement of windows, roof renovation (with or without additional heat insulation) and the construction of a thermal plant. It is clear that these measures can but slightly improve the quality of real estate and make it more attractive (except for new windows). Therefore, partial renovation can hardly change the market value of the apartments considerably.

The state of a building to be renovated is also very important. The number of defects and drawbacks is growing with time. This physical deterioration may be reversed to some extent. However, the obsolescence of the building associated with the lay-out of apartments adds to the situation when its reconstruction becomes economically inefficient, i.e. market value increment of dwelling due to renovation is lower than the cost of renovation. In this case, the following rule should be followed: a contribution of renovation into a general market value of an object rather than the costs of renovation should be evaluated. Investment value in the single most likely scenario is equivalent to market value which would be likely to result in a hold decision and thus the scenario approach potentially provides extra insight [10].

$\mathrm{T}_{0}$ determine the market value of renovated apartments in multistorey buildings, the fol lowing scheme may be used:

Initial real estate market value (known) + market value increment due to real estate renovation (unknown $)=$

Final real estate market value after renovation (unknown).

The initial real estate market value should be determined before the renovation programme is prepared for a particular district. Given 
a certain number of renovated apartment houses in a district and basing ourselves on the data about the prices of the apartments sold (i.e. the increase of their market value) we can forecast the expected market price of the apartments after renovation in this district. It is evident that a complex real estate renovation of a district would result in a higher price increment but the limit will always be the cost of new construction. With the real estate price increment due to a complex renovation of a particular district known, and after renovating several buildings in another district, it is possible to predict the market value increment of renovated apartments in this district.

The price increase due to renovation will depend on the investment made into one dwelling. The renovation scenario should be chosen in such a way that the sum of the initial dwelling market price and the renovation expenses would be by $20-30 \%$ lower than the market value of the most of newly-built apartments in the district. It is clear that these prices will change in time, therefore, before launching the renovation programme in any district, cost analysis of old and new dwellings should be made which would help to choose the best renovation scenario from the perspective of market value increment.

Forecasting the market value of renovated property is a complicated process because there are practically no renovated residential buildings with the improved territories (provided with necessary amenities and equipment). A comparative value analysis would be most suitable for prediction. This method could be applied to the apartment buildings in Žirmūnai where the local government is going to execute some renovation projects. The market value increment could be determined from the analysis of market prices of the renovated apartments sold.

Another approach to determining market value increment could be based on the income value. This would involve the analysis of the rent which could be obtained if a renovated dwelling is rented. However, renting of dwelling in so-called "bedroom" districts is not popular in Vilnius and the application of this method is rather complicated. Therefore, it is only possible to determine general trends of development in this area after the apartment buildings are renovated.

\section{CONCLUSIONS}

The current state of apartment buildings in Vilnius is not satisfactory. Therefore, these houses need to be renovated. The territorial principle of renovation should be followed, implying that the priorities of Vilnius districts requiring renovation of dwelling houses should be stated. The renovation programme should be complex including the improvement of many building components and the surrounding territory. This would make the districts more attractive for investments and increase the value of land.

In order that the market value increment of the renovated property would exceed the investment into its renovation, the renovation scenarios would be chosen in such a way that the average market price of renovated dwellings and the cost of renovation project would not exceed the market value of a newly-built dwelling, i.e. MVR should be more than 1. The increase in the price of dwelling after renovation may be expected if the market price and cost of investment of a renovated apartment is 20 $30 \%$ lower than the value of a newly-built dwelling.

\section{REFERENCES}

[1] F. Flourentzou, C. Roulet, Elaboration of retrofit scenarios, Energy and Buildings, Vol. 34, 2002, p. 185-192.

[2] M. Gorgolewski, Optimising Renovation Strategies for Energy Conservation in Housing, Building and Environment, Vol. 30, 1995, p. 583-589.

[3] S. Gustafsson, Optimisation of insulation measures on existing buildings, Energy and Buildings, Vol. 33, 2000, p. 49-55. 
[4] http://www. hellersdorf2000.de

[5] W. Kleiber, J. Simon and G. Weyers, Verkehrswertermittlung von Grundstiicken. 3. Auflage. Bundesanzeiger Verlags-Ges. MbH., Koln, 1998. $2358 \mathrm{p}$.

[6] V. Klevas, F. Zinevicius, The state significance of energy saving in buildings and principles of support programs in Lithuania, Energy Policy, Vol. 28, 2000, p. $791-798$

[7] Lithuanian Housing strategy, http://www.am.lt/ Tataproj.php

[8] V. Martinaitis, A. Rogoža and 1. Bikmanienè, Criterion to evaluate the "twofold benefit" of the renovation of buildings and their elements, Energy and Buildings, Vol. 36, 2004, p. 3-8.

[9] J. Miljan, K. Sahk, The Appraisal of Structure's Value on the Different Stages of ist Life-Cycle, in Symposium proceedings on Integrated lifetime engineering of buildings and civil infra- structures, Kuopio, Finland, 2003, p. 131-136.

[10] J. Robinson, Asset allocation in balanced portfolios: a note on the place of property, Pacific Rim Real Estate Society, Christchurch, 20-22 January.

[11] J. Robinson, R. Reed, Property illiquidity: the effects of depreciation and obsolescence on returns and values, in Proceedings of the RICS Foundation construction and building research conference, Nottingham Trent University, 5-6 September 2002.

[12] E. K. Zavadskas, A. Kaklauskas, A new method of complex evaluation of projects based on multiple criteria analysis and the principle of proportionality, in D. K. Despotis, C. Zopounidis, eds., Integrating Technology \& Human Decisions: Global Bridges into the $21^{\text {st }}$ Century, Vol. II, Proceedings of $5^{\text {th }}$ International Conference, Athens, Greece, 1999, p. 2051-2053. 